\title{
Linoleyl Carbonate-Paclitaxel
}

National Cancer Institute

\section{Source}

National Cancer Institute. Linoleyl Carbonate-Paclitaxel. NCI Thesaurus. Code C101792.

A formulation of the 6-omeg a fatty acid derivative 2'-linoleyl carbonate (LOC) conjug ated to paclitaxel, a taxane compound extracted from the Pacific yew tree Taxus brevifolia, with potential antineoplastic activity. Paclitaxel binds to and stabilizes tubulin, thereby interfering with the dynamics of microtubule assembly/disassembly and resulting in the inhibition of cell division. LOC enhances the uptake of paclitaxel by tumor cells, thereby concentrating this agent in tumor cells compared to normal cells, and may decrease its toxicity profile; fatty acids serve as energy sources and biochemical precursors for the fast growing tumor cells. 